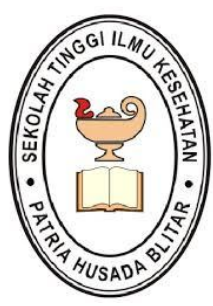

JNK

JURNAL NERS DAN KEBIDANAN

(JOURNALOFNERS AND MIIDWIFERY)

http://jnk.phb.ac.id/index.php/jnk

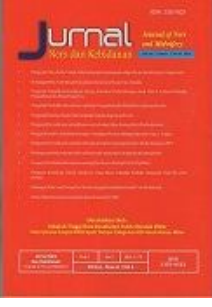

\title{
Questionnaire for Children with Autism Syndrome Disorder
}

Suprajitno $^{1}$, Sri Mugianti ${ }^{2}$

${ }^{1,2}$ Nursing Department, Poltekkes Kemenkes Malang, Indonesia

CrossMark

\begin{tabular}{l}
\hline Article Information \\
\hline History Article: \\
Received, 21/09/2021 \\
Accepted, 20/11/2021 \\
Published, 15/12/2021 \\
Keywords: \\
Autism Syndrome Disorder (ASD), \\
Questionnaire, Family Support, \\
Stimulation, Ability
\end{tabular}

\begin{abstract}
Children with autism syndrome disorder (ASD) have a developed mental condition like normal children in general. However, in Indonesia there is no instrument to measure the achievement of the development of children with autism syndrome disorder. The purpose of this research resulted in a questionnaire used to measure institutional and family support, parental stimulation abilities, and the ability of children with autism syndrome disorder. The design used exploratory for developing of instruments. Experts involved in the development of the instruments were psychologists, occupational therapists, speech therapists, pediatricians, autistic child behavioral therapy practitioners, and the institution of Autism Center of Blitar City. The instrument development began with focus group discussion, instrument preparation, instrument trials, and analysis. The questionnaire trial was conducted on 40 parents and children with ASD at the Autism Center of Blitar City. The analysis was conducted sthrugh several steps namely the validity of the content and construct by experts, while the test of validity and reliability of the questionnaire used Lisrel 8.50. Valid and reliable questionnaires items on the institutional and family support were 21 questions, parents' ability to stimulate as many as 17 questions, and the ability of children with autism syndrome disorder as many as 17 questions. The resulting questionnaire has a minimum GFI score of 0.88 and a CR of 0.78 , so that the questionnaire can be used as a instrument on autism services.
\end{abstract}

(C) 2021 Journal of Ners and Midwifery

$\triangle$ Correspondence Address:

Poltekkes Kemenkes Malang - East Java, Indonesia

P-ISSN : 2355-052X

Email: suprajitno_skp@ poltekkes-malang.ac.id

E-ISSN : 2548-3811

DOI: 10.26699/jnk.v8i3.ART.p315-320

This is an Open Access article under the CC BY-SA license (http://creativecommons.org/licenses/by-sa/4.0/) 


\section{INTRODUCTION}

The number of children with autism syndrome disorder (ASD) in Indonesia has not been well recorded. Children with ASD in the world in 2014 were 1 in 68 children and increased by $15 \%$ to 1 in 59 children in 2018. Meanwhile, WHO predicts 1 in 160 children (Dirjen P2 Penyakit Kemkes RI, 2020).

Family as the first and the main place for children with autism syndrome disorder (Suprajitno, 2017) has a role in knowing health problems and meeting the developmental needs of children. The developmental needs of children with autism syndrome disorder are less able to be met by parents because they do not know the support that needs to be provided, the stimulation skills that need to be had, and the development that the child has been through. The cause of parents does not do developmental stimulation because there was never a measurement tools of the development level of children with autism syndrome disorder.

\section{METHODS}

The design used exploratory for developing of the questionnaires. The development of question items involved experts, namely psychologists, occupational therapists, speech therapists, pediatricians, autistic child behavioral therapy practitioners, and the institution of Autism Center of Blitar City. The development of the instruments was based on the book of Bina Anak Autis di Rumah (Foster Autistic Children at Home) (Suprajitno \& Aida, 2017). The instrument development began with focus group discussion, instrument preparation, instrument trials, and analysis. The questionnaire trial was conducted on 40 parents and children with autism syndrome disorder at the Autism Center in Blitar City. The questionnaire trials were conducted three times in June - September 2017. The questionnaire improvement was conducted twice based on the results of the trials that have been analyzed. The analysis was conducted namely the validity of the content and construct by experts, while the test of validity and reliability of the questionnaire using Lisrel 8.50.

\section{RESULT}

The confirmatory factor analysis results of questioner are listed in Table 1 and questioner for measured (see Appendix 1).

Table 1 The validity and Composite Reliability of Sub-Variable

\begin{tabular}{|c|c|c|c|c|c|c|c|}
\hline No. & Questioner & $\begin{array}{l}\text { Number } \\
\text { of item }\end{array}$ & Sub-variable & Validity & $\begin{array}{l}\text { Compo- } \\
\text { site } \\
\text { reliability }\end{array}$ & $\begin{array}{c}\text { Alpha } \\
\text { Cronbach }\end{array}$ & GF \\
\hline 1 & $\begin{array}{l}\text { Institutional and } \\
\text { family support }\end{array}$ & $\begin{array}{l}1 \text { to } 4 \\
5 \text { to } 9 \\
10 \text { to } 15 \\
16 \text { to } 21\end{array}$ & $\begin{array}{l}\text { Autism Centre support } \\
\text { The family emotional support } \\
\text { The family informational support } \\
\text { The family instrumental support }\end{array}$ & $\begin{array}{l}0.98 \\
0.92 \\
0.96 \\
0.88\end{array}$ & $\begin{array}{l}0.83 \\
0.78 \\
0.88 \\
0.93\end{array}$ & $\begin{array}{l}0.74 \\
0.65 \\
0.83 \\
0.91\end{array}$ & $\begin{array}{l}0.98 \\
0.92 \\
0.96 \\
0.88\end{array}$ \\
\hline 2 & $\begin{array}{l}\text { Parental stimulation } \\
\text { ability }\end{array}$ & $\begin{array}{l}1 \text { to } 5 \\
6 \text { to } 9 \\
10 \text { to } 17\end{array}$ & $\begin{array}{l}\text { The parent stimulation of fine } \\
\text { motoric ability for children with ASD } \\
\text { The parent stimulation of socialization } \\
\text { ability for children with ASD } \\
\text { The parent stimulation of language } \\
\text { ability for children with ASD }\end{array}$ & $\begin{array}{l}0.96 \\
0.94 \\
0.75\end{array}$ & $\begin{array}{l}0.79 \\
0.81 \\
0.91\end{array}$ & $\begin{array}{l}0.67 \\
0.68 \\
0.89\end{array}$ & $\begin{array}{l}0.96 \\
0.94 \\
0.75\end{array}$ \\
\hline 3 & $\begin{array}{l}\text { Ability of children } \\
\text { with ASD }\end{array}$ & $\begin{array}{l}1 \text { to } 5 \\
6 \text { to } 11 \\
12 \text { to } 17\end{array}$ & $\begin{array}{l}\text { The fine motoric ability of children } \\
\text { with ASD } \\
\text { The socialization ability of children } \\
\text { with ASD } \\
\text { The language ability of children } \\
\text { with ASD }\end{array}$ & 0.86 & 0.85 & 0.78 & 0.86 \\
\hline
\end{tabular}

GFI = Goodness of Fit Index; ASD = Autism Syndrome Disorder 


\section{DISCUSSION}

Validity and reliability are the two most important and fundamental in the evaluation of measurement instrument or tools (Forthofer et al., 2007; Frost, 2019; Mohaffyza Mohamad et al., 2015). Analysis of validity used Pearson correlation and reliability used Cronbach's alpha (Forthofer et al., 2007; Frost, 2019). The purpose of testing the validity and reliability is to ensure that the questionnaire used is good for measuring the expected data. Confirmatory factor analysis aims to confirm the indicators as a statement of the data collected (Brown, 2015; Long, 1992; Thompson, 2004).

The Pearson coefficients between 0 and \pm 0.30 show low, the coefficients between \pm 0.31 and \pm 0.70 indicate medium and the coefficients between \pm 0.71 and \pm 1 point out high relationships (Shevlyakov \& Oja, 2016). Meanwhile, the Pearson coefficient and reliability if $<0.67$ show Poor, 0.67 to 0.80 indicate Fair, $0.81-0.90$ indicate Good, 0.91 - 0.94 indicate Very Good, and >0.94 indicate Excellent (Mohaffyza Mohamad et al., 2015). The minimum value of validity 0.75 and reliability 0.65 (Table 1). So statistically, the validity and reliability of indicators of the questionnaire are in the Good Excellent category.

The assessment of the question indicators in the questionnaire used confirmatory factor analysis together using Lisrel. The aim is to confirm the suitability of the indicators with the theory used. The results of indicator confirmation with theory are seen from GFI results. Goodness of fit index (GFI) is an index that describes the level of suitability of the overall model which is calculated from the squared residual of the predicted model compared to the actual data. The GFI value $>0.90$ indicates that the tested model has a good fit (Brown, 2015; Long, 1992; Thompson, 2004). Even though the lowest GFI value (Table 1 ) is 0.75 , theoretically this indicator is needed, so it can still be used as a measurement indicator. The limitations of this instrument are not yet classifying the ability of parents and children with ASD in a criterion.

\section{CONCLUSION}

The minimum value of validity and reliability of the questionnaire is 0.75 and 0.65 in both categories so that it can be used to measure institutional and family support, parental stimulation ability, and the ability of children with ASD.

\section{SUGGESTION}

Questionnaires can be used to assess the support of educational institutions for autistic children, the ability of parents to stimulate, and the ability of children with ASD. It is hoped that the questionnaire can be developed as a predictive tool for the ability of children with ASD.

\section{REFFERENCE}

Brown, T. A. (2015). Confirmatory Factor Analysis for Applied Research. In The American Statistician (Second, Vol. 62, Issue 1). The Guilford Press. https:/ /doi.org/10.1198/tas.2008.s98

Dirjen P2 Penyakit Kemkes RI. (2020). Hari Peduli Autisme Sedunial : Pentingnya Pendampingan dan Edukasi bagi Anak Gangguan Spektrum Autisme ditengah Pandemi Covid-19. http:// p2p.kemkes.go.id/hari-peduli-autisme-seduniapentingnya-pendampingan-dan-edukasi-bagi-anakgangguan-spektrum-autisme-ditengah-pandemicovid-19/

Forthofer, R. N., Lee, E. S., \& Hernandez, M. (2007). Biostatistics: Analysis, and to Design, A Guide Discovery. Elsevier. http://library.lol/main/ 5EB8824580E860997136DA1C7C215AFC

Frost, J. (2019). Introduction to Statistics. Statistics By Jim Publishing. https://statisticsbyjim.com/basics/ correlations/

Long, J. S. (1992). Confirmatory Factor Analysis: A Preface to Lisrel. Quantitative Applications in the Social Sciences. Sage Publications.

Mohaffyza Mohamad, M., Lisa Sulaiman, N., Chee Sern, L., \& Mohd Salleh, K. (2015). Measuring the Validity and Reliability of Research Instruments. 4th World Congress on Technical and Vocational Education and Training (WoCTVET), 5th-6th November 2014, Malaysia, 204, 164-171. https://doi.org/ 10.1016/j.sbspro.2015.08.129

Shevlyakov, G. L., \& Oja, H. (2016). Robust Correlation Theory and Applications. John Wiley \& Sons, Ltd. h t t p : / / 1 i b r a r y . 1 o $1 /$ m a i n / ODA2CF00E440F37F50CD9D831ED70F53

Suprajitno. (2017). Effect of Family Empowerment in Enhancing the Capabilities of Children with Autism. Belitung Nursing Journal, 3(5), 533-540. https:// doi.org/10.33546/bnj.113

Suprajitno, \& Aida, R. (2017). Bina Aktivitas Anak Autis di Rumah/: Panduan bagi Orang Tua. Media Nusa Creative. http://mncpublishing.com/bookdetail.php?id=000095

Thompson, B. (2004). Exploratory And Confirmatory Factor Analysis: Understanding Concepts and Applications. In Acta Geophysica (First, Vol. 58, Issue 4). American Psychological Association. 


\section{Appendix 1: Questionnaire}

1. Questionnaire to measure of family perception about the Institutional and Family Support

How to fill in: Put a check $(\sqrt{ })$ on the column that you feel best represents your answer.

\begin{tabular}{|c|c|c|c|c|c|}
\hline \multirow[b]{2}{*}{ No. } & \multirow[b]{2}{*}{ Statements } & \multicolumn{4}{|c|}{ That is felt } \\
\hline & & Never & Ever & Often & $\begin{array}{l}\text { Very } \\
\text { often }\end{array}$ \\
\hline 1 & $\begin{array}{l}\text { I got an explanation about my child's education program plan at the } \\
\text { Autism Center }\end{array}$ & & & & \\
\hline 2 & $\begin{array}{l}\text { I got information from the Autism Center about my child's education } \\
\text { activities next week }\end{array}$ & & & & \\
\hline 3 & $\begin{array}{l}\text { I got an explanation of my child's last ability after being given therapy } \\
\text { at Autism Center }\end{array}$ & & & & \\
\hline 4 & I got a chance to ask about my child's development & & & & \\
\hline 5 & My family feels responsible for education & & & & \\
\hline 6 & My family protects the child while at home and playing & & & & \\
\hline 7 & $\begin{array}{l}\text { My family explains to other families that my child's condition is not a } \\
\text { disease }\end{array}$ & & & & \\
\hline 8 & $\begin{array}{l}\text { My family is encouraging during the upbringing if anyone is sad about } \\
\text { the state of the child }\end{array}$ & & & & \\
\hline 9 & $\begin{array}{l}\text { My family remembers the education program needs to be done } \\
\text { according to plan }\end{array}$ & & & & \\
\hline 10 & $\begin{array}{l}\text { My family provides corrections about the actions that have been done } \\
\text { to the child }\end{array}$ & & & & \\
\hline 11 & My family is looking for information on how to educate a child & & & & \\
\hline 12 & My family gives examples of ways to improve the ability of a child & & & & \\
\hline 13 & My family creates a comfortable environment for a child & & & & \\
\hline 14 & My family provides a book that matches the child's condition & & & & \\
\hline 15 & $\begin{array}{l}\text { My family provides information on places of education for a child } \\
\text { other than the Autism Centre }\end{array}$ & & & & \\
\hline 16 & My family asked about the educational needs of children & & & & \\
\hline 17 & My family provided about the educational needs of children & & & & \\
\hline 18 & My family maintains the educational tools of children & & & & \\
\hline 19 & My family uses well the educational tools needed by the child & & & & \\
\hline 20 & My family maintains the educational tools that children need & & & & \\
\hline 21 & My family is repairing the educational tools of children & & & & \\
\hline
\end{tabular}


2. Questionnaire to measure of the Parental Stimulation Ability

How to fill in: Put a check $(\sqrt{ })$ on the column that you feel best represents your answer.

\begin{tabular}{|c|c|c|c|c|c|}
\hline \multirow[b]{2}{*}{ No. } & \multirow[b]{2}{*}{ Statements } & \multicolumn{4}{|c|}{ That is felt } \\
\hline & & Cannot & $\begin{array}{c}\text { Needs } \\
\text { help }\end{array}$ & Can & Skillful \\
\hline 1 & Crawling under a cloth tunnel & & & & \\
\hline 2 & Manipulating face in front of the mirror & & & & \\
\hline 3 & Touching and holding objects round or box & & & & \\
\hline 4 & Colouring the image using a dye & & & & \\
\hline 5 & Singing a song that his/her favourite & & & & \\
\hline 6 & Lending a favourite toy to the child's friends & & & & \\
\hline 7 & Following orders given by the child or others & & & & \\
\hline 8 & Engaging other children to play the same & & & & \\
\hline 9 & Imitates or modifies the movements of other children & & & & \\
\hline 10 & Giving simple reading material & & & & \\
\hline 11 & Giving simple calculating materials & & & & \\
\hline 12 & Asking the child to write the name of their parents and sister/brother & & & & \\
\hline 13 & Asking the child to write the name of a playmate or someone familiar & & & & \\
\hline 14 & Asking children to write good free sentences & & & & \\
\hline 15 & Asking the child to sing the child's song & & & & \\
\hline 16 & Asking the child to imitate the song being heard & & & & \\
\hline 17 & Asking the child to concentrate on watching television & & & & \\
\hline
\end{tabular}


3. Questionnaire to measure ability of the children with ASD

How to fill in: Put a check $(\sqrt{ })$ on the column that you feel best represents your answer.

\begin{tabular}{|c|c|c|c|c|}
\hline \multirow[b]{2}{*}{ No. } & \multirow[b]{2}{*}{ Statements } & \multicolumn{3}{|c|}{ That is felt } \\
\hline & & Cannot & $\begin{array}{c}\text { Needs } \\
\text { help }\end{array}$ & Skillful \\
\hline 1 & Hand in hand with children or adults for at least 5 minutes & & & \\
\hline 2 & Imitating the highlighted halos on the wall & & & \\
\hline 3 & Following the direction of the highlighted light on the wall & & & \\
\hline 4 & Blowing balloon bubbles made of soapy water & & & \\
\hline 5 & Concentrates when getting orders until the command is finished & & & \\
\hline 6 & Sharing toys that are desired by a child's friend & & & \\
\hline 7 & Sharing food with children nearby & & & \\
\hline 8 & Invites other children to follow the game & & & \\
\hline 9 & $\begin{array}{l}\text { Does activities by following the orders of other children who are considered } \\
\text { leaders }\end{array}$ & & & \\
\hline 10 & Helping other children who carry out activities & & & \\
\hline 11 & Reports the ability of yourself or another child & & & \\
\hline 12 & Mentions the names of father, mother, and siblings & & & \\
\hline 13 & Mentions a friend's name, of at least 5 people & & & \\
\hline 14 & Mentions a minimum of 10 consecutive letters & & & \\
\hline 15 & Mentions a minimum of 8 consecutive numbers & & & \\
\hline 16 & Writes sentences according to the example & & & \\
\hline 17 & Reads sentences according to examples & & & \\
\hline
\end{tabular}

